\title{
Oxidizing Effect of Ozonated-Water on Microbial Balance in the Oral Ecosystem
}

\author{
Fathilah Abdul Razak1, Md. Yusoff Musa², Husham Amra Mahmod Abusin² and Nosizana Mohd. Salleh³
}

\begin{abstract}
Application of ozone is recommended for sterilisation in dental procedures. This study explored the antimicrobial effect of $0.1 \mathrm{ppm}$ ozonated-water on selected common oral commensals. Based on deviation of their growth curves pattern upon ozone treatment, the inhibitory effect of ozone was determined. SEM examination of the ozone-treated microbes recorded its possible morphological effect. Findings suggested a bacteriostatic action of ozone when microbes were treated at the early phase, while, it was bactericidal when treated during the active phase of the growth cycle. Hence, suggesting rinsing the oral cavity with ozonated-water at $0.1 \mathrm{ppm}$ immediately after tooth brushing may suppress microbial growth and slow biofilm formation. While, rinsing on already developed biofilm may result in microbial cell lysis that halted microbial growth and reduce microbial population in the biofilm. Both justify the great potential of ozone $(0.1 \mathrm{ppm})$ for use as antimicrobial agent for the control of biofilm development in the oral cavity.
\end{abstract}

Key Words: Bacteriostatic, Bactericidal, Candida, Oral biofilm, Streptococcus.

The non-shedding surfaces of tooth tissue secure undisturbed adhesion of various types of oral microbes, forming supragingival and subgingival plaque, respectively above and below the gingival margin. Unless mechanically removed, this biofilm remains attached and accumulates. ${ }^{1}$ Dental caries and gum problem are diseases closely associated with the oral biofilm; and are initiated when oral hygiene is neglected and biofilm is left unattended. Other microbes in the mouth resides on surfaces of the mucosa and in oral fluids. Together, these microbes constitute the commensal community of the oral ecosystem. ${ }^{2}$ Ozone, with its powerful disinfection property, is deemed as the perfect substance for use in dental procedures as it disinfects the treated tissues and leaves no toxic residues such as chlorinated products. ${ }^{3}$ However, ozone was reported toxic at concentration of more than $0.1 \mathrm{ppm} .{ }^{4}$ Thus, as an antimicrobial agent for oral care purposes, ozone must be formulated in sufficient concentration, in an appropriate method and for an adequate time. The growth pattern of a microbe under an undisturbed condition follows a sigmoidal curve with a lag, logarithmic and stationary growth phases.

\footnotetext{
1 Department of Oral and Craniofacial Sciences, University of Malaya, Kuala Lumpur, Malaysia

2 Institute of Biological Sciences, University of Malaya, Kuala Lumpur, Malaysia

3 Department of Restorative Dentistry, University of Malaya, Kuala Lumpur, Malaysia

Correspondence: Dr. Fathilah Abdul Razak, Department of Oral and Craniofacial Sciences, University of Malaya, 50603,

Kuala Lumpur, Malaysia

E-mail: fathilah@um.edu.my

Received: October 13, 2017; Accepted: November 19, 2018
}

A deviated curve pattern would indicate interrupted growth activities and functions. 5

This study aimed to determine the effect of ozonated-water at $0.1 \mathrm{ppm}$ on the growth of common oral commensals.

Three common oral microbes that included Streptococcus mitis, Actinomyces sp. and Candida albicans were cultured in BHI (Brain heart infusion, Oxoid) broth, incubated at $37^{\circ} \mathrm{C}$ while changes in the turbidity were periodically monitored. Growth curves were plotted and durations of the lag and log phases determined. The procedure was repeated but with treatment of ozone (0.1 ppm) at two different time intervals; $\left(t_{0}\right)$ ozone treatment at zero time, and $\left(t_{1}\right)$ ozone treatment at the mid-log phase of growth. Dissolved ozone (0.1 ppm) was introduced from a discharge ozone gas generator ORM AW600 into the BHI broth. Upon completion of a growth cycle, the generation time $(\mathrm{g})$ and growth rates $(\mu)$ were determined. ${ }^{6}$ Any deviations of $g$ and $\mu$ from the normal pattern were compared and analysed. A millilitre of growth suspension of each microbe was also aliquoted at $\left(t_{1}\right)$ and the cells were captured on nitrocellulose discs, fixed and processed for SEM examination.

Untreated S. mitis, Actimonyces sp. and C. albicans displayed normal sigmoidal growth curves with a 3-4 hours of lag period and log phase achieved at the $6^{\text {th }}-7^{\text {th }}$ hour for S. mitis and C. albicans. The log phase for A. viscosus was attained earlier at the 3rd hour of growth (Figure 1). Ozone treatment given at the beginning of the growth cycles $\left(\mathrm{t}_{0}\right)$ resulted in extended lag phase (Figures $1 \mathrm{a}, \mathrm{b}, \mathrm{c}$ ) and suppressed cells growth that lead to reduced maximum cell population. $S$. mitis was most affected with a $37 \%$ decreased in $(\mathrm{g})$ followed by $A$. viscosus and $C$. albicans at $33 \%$ and $28 \%$, respectively. No morphological effect of $0.1 \mathrm{ppm}$ ozone was 
seen in the SEM micrographs (Figure 2). Cell size with diameters of $1.1 \pm 0.1 \mu \mathrm{m}$ and $0.96 \pm 0.1 \mu \mathrm{m}$ were maintained for $S$. mitis and $C$. albicans, respectively while, $A$. viscosus at $3.4 \pm 0.2 \mu \mathrm{m} \times 0.8 \pm 0.1 \mu \mathrm{m}$ (Figure 2 $c, d)$. The SEM micrographs, however, showed obvious reduction of cell numbers following ozone-treatment.

Microorganisms require energy to maintain a complete growth cycle. Following an early exposure of the microbes to ozone, a delayed growth activity ( $\mathrm{g}$ ) as indicated by the extension of the lag phase, suggested a longer adaptive period was required by the ozone-treated microbes to generate sufficient energy to support increment of cellular components and divide successfully

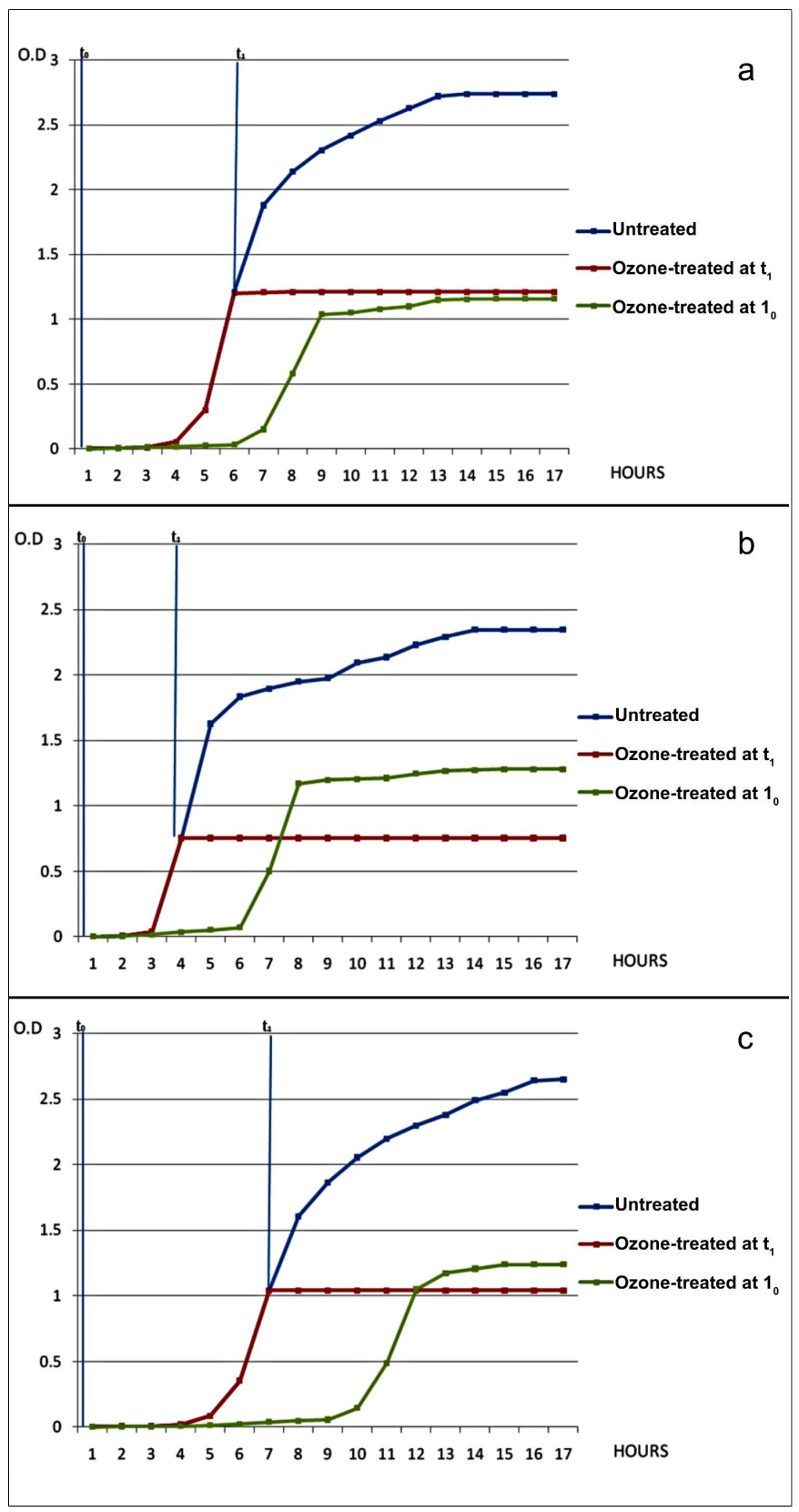

Figure 1: Growth curves of (a) S. mitis (b) A. viscosus and (c) C. albicans exhibiting sigmoidal pattern under the untreated growth condition (blue line). Deviated growth curves were obtained following $0.1 \mathrm{ppm}$ ozone treatments at $\mathrm{t}_{0}$ (green line) and $\mathrm{t}_{1}$ (red line).
(Table I). Introduction of ozone into the growth environment at $\mathrm{t}_{0}$ may have altered the oxygen form in the media from $\mathrm{O}_{2}$ to $\mathrm{O}_{3}$. With reduced availability of oxygen to carry out physiological processes, the microbial cells at the early lag phase experienced intense physiologic adjustments to adapt to the new altered growth condition. The adaptive period for $S$. mitis, $A$. viscosus and $C$. albicans was slightly different (Figure $1 \mathrm{a}, \mathrm{b}, \mathrm{c}$ ) as different type of microorganisms responded differently to environmental stress. ${ }^{7}$ However, ozone is not stable and will revert back to $\mathrm{O}_{2}$, which lifted the stress from the environment. This explains why the growth curves eventually entered the log phase after an extended lag

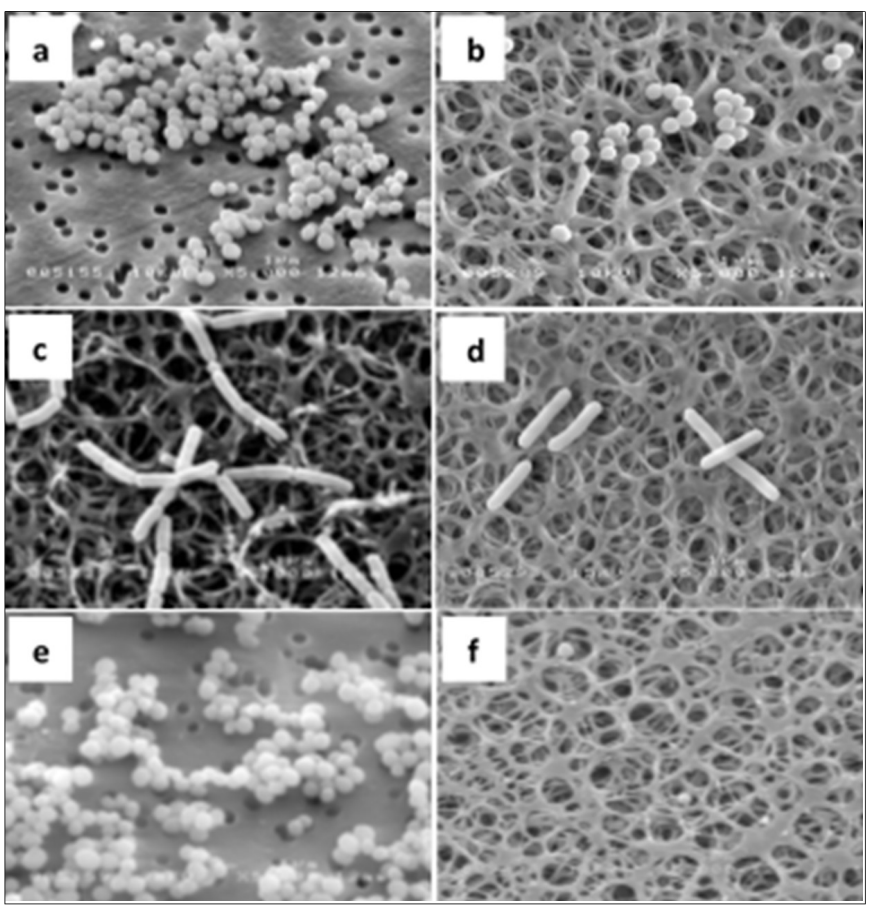

Figure 2: SEM micrographs of $\mathrm{S}$. mitis ( $\mathrm{a}$ and $\mathrm{b}$ ), $A$. viscosus (c and d) and C. albicans (e and f) before and after treatment with $0.1 \mathrm{ppm}$ ozonated-water. (5000x).

Table I: Growth inhibitory effect of ozone $(0.1 \mathrm{ppm})$ on common oral commensal based on the generation time $(\mathrm{g})$ and growth rate $(\mu)$.

\begin{tabular}{l|l|ccc}
\hline Bacteria & Generation & \multicolumn{3}{|c}{ Growth conditions } \\
\cline { 3 - 5 } & Time $(g)$ and growth & Untreated & $\begin{array}{c}\text { Ozone } \\
\text { treated } \\
\text { at }\left(\mathrm{t}_{0}\right)\end{array}$ & $\begin{array}{c}\text { Ozone } \\
\text { treated } \\
\text { at }\left(\mathrm{t}_{1}\right)\end{array}$ \\
\hline \multirow{2}{*}{ S. mitis } & $\mathrm{g}(\mathrm{hr})$ & & $2.0 \pm 0.1$ & $1.0 \pm 0.1$ \\
& $\mu\left(\mathrm{hr}^{-1}\right)$ & $1.0 \pm 0.1$ & $2.5 \pm 0.1$ & $3.0 \pm 0.1$ \\
& Increased $g$ & $4.0 \pm 1.0$ & 2 -fold & 0 -fold \\
& Reduced $\mu$ & - & $37 \%$ & $25 \%$ \\
\hline A. viscosus & $\mathrm{g}(\mathrm{hr})$ & - & $1.0 \pm 0.1$ & $0.7 \pm 0.04$ \\
& $\mu(\mathrm{hr}-1)$ & $3.0 \pm 0.1$ & $2.0 \pm 0.1$ & $2.5 \pm 0.2$ \\
& Increased $g$ & - & $2-$ fold & $1.4-$-fold \\
& Reduced $\mu$ & - & $33 \%$ & $16 \%$ \\
\hline C. albicans & $\mathrm{g}(\mathrm{hr})$ & $1.0 \pm 0.1$ & $1.5 \pm 0.1$ & $1.1 \pm 0.02$ \\
& $\mu$ (hr-1) & $4.3 \pm 0.1$ & $3.1 \pm 0.3$ & $2.2 \pm 0.2$ \\
& Increased $g$ & - & 1.5 -fold & 0.1 -fold \\
& Reduced $\mu$ & - & $28 \%$ & $49 \%$ \\
\hline
\end{tabular}


period. Other than reduction in cell population, ozone did not affect the morphology of the microbial cells (Figure 2).

Interestingly, an abrupt inhibition of cell growth was instead seen in all three microorganisms when ozone was given later at the log phase of growth. Application of ozone at the middle of the log phase where cells were at their maximum growth rate $\left(t_{1}\right)$ was seen to instantaneously suppressed the growth curves from a log to a stationary phase. This indicated the bactericidal effect of ozone, whereby disruption of microbial cell wall may have led to loss of cellular contents or in other words, the bacterial cells were lysed. ${ }^{6}$ Therefore, the plateau attained following treatment of ozone at $t_{1}$ is to be expected as no more multiplication of microbes can occur due to the bactericidal activity of ozone. The absorbance, however, did not drop to zero because measurements based on absorbance readings correspond to the presence of both life and dead cells 5 and this explains the results presented.

Data gathered suggests that rinsing the oral cavity with ozonated-water at $0.1 \mathrm{ppm}$ immediately after tooth brushing may result in a bacteriostatic effect, whereby formation of oral biofilm is slowed down. While, rinsing on already developed biofilm may result in a bactericidal effect that halts microbial growth and reduce microbial population in the biofilm. Both justify the great potential of ozone $(0.1 \mathrm{ppm})$ for use as antimicrobial agent in the control of biofilm development in the oral cavity.

Disclosure: Financial support for the study was obtained from the High Impact Research MoE Grant (UM.C/625/1/ $\mathrm{HIR} / \mathrm{MoE} / 15$ ) from the Ministry of Education Malaysia.

\section{REFERENCES}

1. Marsh PD. Role of the oral microflora in health. Microbiol Ecol Health Dis 2000; 12:130-7.

2. Gurenlian JR. The role of dental plaque biofilm in oral health. J Dent Hygiene 2007; 81:1-11.

3. Manish K, Abhishek H, Ravi H. Deepak M. Ozone therapy in dentistry - A review. GCC J Sc Tech 2015; 1:181-5.

4. Sadatullah S, Mohamed NH, Fathilah AR. Ozone in dentistry: What dentists should know about this gas? J King Saud Univ Dent Sci 2011; 2:83-7.

5. Gerhardt P, Murray RGE, Costilow RN, Willis WA, Krieg NR, Phillips GB. Manual of methods for general bacteriology, American society for microbiology, USA; 1981.

6. Fathilah AR, Rahim ZHA, Othman R, Yusoff M. Bacteriostatic effect of Piper betle and Psidium guajava extracts on dental plaque bacteria. Pak J Biol Sci 2009; 12:518-21.

7. Fathilah AR, Aishah A, Zarina MZ. The effect of environmental stress on the growth of plaque bacteria. Res J Microbiol 2007; 2:381-6. 